The First International Conference of The Faculty of Al-Alsun, Minia University Egypt in World Literature 14-15 April 2004

\title{
Phonological, Lexical, Structural, and Semantic Aspects of Shakespeare's Antony and Cleopatra: \\ A Diachronic Study
}

\section{Introduction}

When Shakespeare wrote Antony and Cleopatra in about 1606, he was not probably aware that he was communicating to the twenty-first century reader more meanings than he ever wanted; nor was he probably conscious that he was addressing an audience much larger than he thought. His play is fascinating in more ways than one. Not only does it capture Antony's excessive fascination with Cleopatra's Egypt and the ensuing conflict he experiences between his deep love for the Egyptian charming queen and his duty as a political and military commander, but it also captures the linguistic state of affairs prevalent in the late sixteenth and early seventeenth century. Taken as a linguistic document, the play reflects the way the English language was in Shakespeare's time. The phonological, lexical, structural, and semantic features of Elizabethan English are but some of the linguistic implications that Shakespeare unconsciously conveys in Antony and Cleopatra.

Though belonging to Modern English, Antony and Cleopatra displays linguistic features that mark major differences between Elizabethan English and the English spoken and written today. The differences, however, appear to be much less dramatic than those between Shakespeare's English and Chaucer's. While this paper is concerned with the evolution Modern English has undergone over the past four hundred years, it will rule out substandard varieties of English.

Although the language of Antony and Cleopatra is poetic, written mostly in iambic pentameter, it can still lend itself to comparison with presentday English in many respects. The analysis below will point out differences between Elizabethan English and the English spoken and 
written today in the areas of pronunciation, the use of nouns, pronouns, verbs and adjectives, the way words were inflected and structured, and the way some of Shakespeare's words came to acquire new meanings in the course of four hundred years.

\title{
II. Phonological features
}

In the absence of phonograph records and tape recordings, it is no easy task to reconstruct Elizabethan English pronunciation and find out how similar or dissimilar it is to present-day English pronunciation. Fortunately, written records provide some important clues as to how words were pronounced in the sixteenth century and earlier. Among the best clues to Elizabethan English pronunciation are spelling conventions, rhymes, and puns in the literary works of the time, notably Shakespeare's. Such clues indicate that Shakespeare's pronunciation differed from present-day pronunciation in some respects. For example, some rhymes and puns indicate that vowel sounds represented by the ea spelling were pronounced [e], and not [i] as in current pronunciation. A rhyme occurring in Antony and Cleopatra shows that Shakespeare pronounced fear as fair, as evident in Charmian's advice to Cleopatra not to provoke Antony too far:

Tempt him not so too far. I wish, forbear, In time we hate that which we often fear. (I.iii.12)

A similar rhyme is found in the opening scene of Macbeth, where the word heath rhymes with Macbeth, which suggests that the word was pronounced [he: $\theta$ ] in Elizabethan English, and not [hi: $\theta$ ] as it is pronounced today. The witches ask:

\author{
FIRST WITCH Where the place? \\ SECOND Upon the heath. \\ WITCH \\ THIRD WITCH There to meet with Macbeth. (Macbeth, I.i.7)
}

A pun on the words reason and raisin in Henry $I V$, Part $I$ leads to the same conclusion. In Faltsaff's statement, "If reasons were as plentiful as blackberries, I would give no man a reason upon compulsion," reasons and raisin are homophones.

The [e:] sound represented by the ea spelling continued to be pronounced $[\mathrm{e}:]$ in the eighteenth century, as evident in the poetry of Pope, where tea rhymes with obey: 
Here thou, great Ana! Whom three realms obey,

Dost sometimes counsel take - and sometimes Tea. (The Rape of the Lock).

Thus, one can infer that in Antony's utterance to Pompey: "We'll speak with thee at sea" (II.vi.25), the words speak and sea sound as [spek] and [se].

The change of [e:] into modern [i:] is best understood as part of a gradual and systematic series of changes that affected all long vowels between the fifteenth and eighteenth century. Known as the Great Vowel Shift (GVS), the movement involved vowel raising and diphthongization of high vowels. Over the years during this period the long vowels came to be pronounced with a greater elevation of the tongue and closing of the mouth while those which could not be raised any more such as [i:] and [u:] were transformed into the diphthongs [ay] and [aw] respectively. Yule (1985) humorously depicts some of these changes: "Chaucer lived in what would have sounded like a 'hoos', with his 'weef', and 'hay' would romance 'heer' with a bottle of 'weena', drunk by the light of the 'moan"' (p.174).

With GVS accomplished, Chaucer's Middle English long vowel [i:] became Modern English [ay], [e:] became [i:], [e:] became [e:], [a:] became [e:], [o:] became [o:], [0:] became [u:], and [u:] became [aw].

GVS marks the last major barrier between early English and the presentday standard English (Crystal, 1990). Once complete, there seemed to be a lull in linguistic change. While sounds continued to change they did so with a much slower pace.

The pronunciation of tea as [te] in Pope's poetry shows that by Shakespeare's time some phonological changes had already been accomplished while others were still underway but not complete. Among the changes that had already been accomplished was the transformation of Chaucer's Middle English long vowels [e:] into [i:], [a:] into [e:], [o:] into [u:]; [ $\varepsilon:]$ into $[\mathrm{e}:]$, and $[\mathrm{J}:]$ into [o:]. The change of the old value $[\varepsilon:]$ into Modern English [i:] was still underway, and the vowel was pronounced by Shakespeare as [e:]. ${ }^{2}$ Also, the evolution of [i:] into [ay], and [u:] into [aw] may not have been fully attained in Shakespeare's day, but was apparently well on the way (Baugh and Cable, 1993). It is quite likely that in the heroic couplet below, the phrase "our lives" sounded like [u:r li:vz]:

Be't as our gods will have't! It only stands

Our lives upon to use our strongest hands. (II.i.51)

While the gulf between Chaucer's and Shakespeare's pronunciation is unmistakable, the gap between Shakespeare's and current pronunciation 
is not all that wide. By Shakespeare's time, most of the long vowel sounds had acquired approximately their present pronunciation. The only exceptions were the Middle English [e:] which became [e:] as still heard in the vowel sounds of break, great and steak, (which' survived as an exception), and the high vowels [i:] and [u:] which were transformed respectively into [ay] and [aw] either fully after Shakespeare or in part during his day. The change of Shakespeare's [e:] in words like clean [kle:n] into [i:] as in the present pronunciation [kli:n] took place at the end of the seventeenth century and had become general by the middle of the eighteenth (Baugh and Cable, 1993).

There is also evidence that in Shakespeare's time the vowel represented with the $o o$ spelling was pronounced [o] as in the current pronunciation of brooch [broč] which retains its old vowel sound. The word room was pronounced [rom], as indicated by Cassius' pun in Julius Caesar, in which room sounds like Rome:

Now is it Rome indeed, and room enough, When there is in it but one only man. (Julius Caesar, I.ii.157)

By analogy, [rom] is the pronunciation of room in Scarus' speech in Antony and Cleopatra:

We'll beat 'em into bench-holes: I have yet

Room for six scotches more. (IV.vii.15)

Cassius' Rome-room pun suggests that the fifteenth-century value [o:] had not, by Shakespeare's time, changed yet into [u:] in words containing the Middle English vowel $\bar{o}$. It is possible, however, that the older [0:] was retained in some words containing. $\bar{o}$ such as room, but replaced in others with the sound [u:] which has remained in current pronunciation in words like moon, roof, and food. In some other words it was shortened and rounded to $[\Lambda]$ as in flood. The fact that a phonological change can affect some words, and not others, at a particular point of time is not particularly controversial. When phonological changes occur they do not affect all words at once, but as Aitchison (1992) remarks, rather move across the language from one word to another "like apples on a tree, which ripen around the same time, but not simultaneously" (p.139). Thus when Enobarbus describes Cleopatra's barge, it is not clear whether the word poop in "the poop was beaten gold" (II.ii.95) was' pronounced with the fifteenth-century value [po:p] or with the evolved value [pu:p] that has survived since. 
Shakespeare's short vowel sounds in stressed syllables did not seem to change much from Chaucer's. The only exceptions were the sounds represented by the Middle English $a$ and $u$. By the end of the sixteenth century Chaucer's $a$ came to be pronounced [æ] as in cat and $u$ became $[\Lambda]$ as in hut. Chaucer pronounced $u[\mathrm{U}]$ as in full, but by Shakespeare's time the $[\mathbf{U}]$ had evolved into $[\Lambda]$, and has remained as such ever since, except after labials as in full, put, wood, bull (Lehmann, 1992).

Another Aspect of Shakespeare's pronunciation was the pronunciation of [r] wherever it occurred. The disappearance of the $[r]$ before consonants and in final position was a phonological addition that did not exist before the year 1607 (Fromkin and Rodman, 1983). Wherever spelled, the [r] was pronounced by the colonial settlers of America and by their countrymen who remained in England. Thus farm, mother, and march

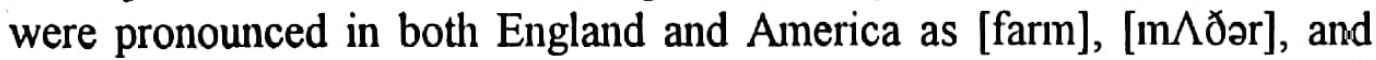
[marč] respectively. But between 1607 and 1900 the grammar of British English and the grammars of the English spoken by the American settlers in Boston underwent an interesting change, namely the addition of a phonological rule stipulating that the $[\mathrm{r}]$ must be pronounced only when it occurs before a vowel. This rule was not added to the grammars of many other Americans (p.285). The loss of the $r$ in the aforementioned grammars also affected the preceding vowel: "From texts over several centuries, we know that in standard British English the syllable-final $r$, as in year, has been lost, with lengthening of the preceding vowel" (Lehmann, 1992, p.3). The loss of $r$ and the flat $a$ in words like fast, path, etc, which were preserved in General American, took place in southern England at the end of the eighteenth century (Baugh and Cable, 1993, p. 354). Thus, in the dialog below, the [r] is pronounced in the words billiards, Charmian, arm, sore, Mardian, sir, short, actor and pardon, where they would be dropped in current standard British pronunciation:

CLEOPATRA Let it alone, let's to billiards: come, Charmian.

CHARMIAN My arm is sore; best play with Mardian.

CLEOPATRA As well a woman with an eunuch played

As with a woman. Come. You'll play with me, sir?

MARDIAN As well as I can, madam.

CLEOPATRA And when good will is showed, though't come too short, The actor may plead pardon. I'll none now. (II.v.9)

The use of the indefinite article an before eunuch in the quotation above indicates that the word was pronounced without the initial palatal glide [y] as in today's pronunciation. The use of the same indefinite determiner before one also shows that Shakespeare did not pronounce one with a 
labiovelar glide as it is the case today [ $\mathrm{w} \Lambda \mathrm{n}]$, but like own [on]. This is evident in the attendant's reply to Antony's request: "The man from Sycon! Is there such an one?" (I.ii.105)

Further, Shakespeare's pronunciation of the vowel sound in sir in the above quotation is not the same as today's pronunciation. Nor is it similar to that in serve or to that in purple in the soothsayer's prediction: "You shall outlive the lady whom you serve" (I.ii.29), and in Enobarbus' description of Cleopatra's barge "Purple the sails" (II.ii.196). The difference in quality of the three vowel sounds in sir, serve, and purple is attributed to the fact that the falling together of $e r$, ir, and ur. was not yet completed, though still underway (Baugh and Cable, 1993).

Shakespearean pronunciation is also different from current pronunciation with respect to accent. The iambic pentameter, with which Antony and Cleopatra is written, also contributes important clues as to the way some words were pronounced during Shakespeare's time. For example, the word cement, which is now pronounced with a stress on the second syllable, once had the stress on the first. This is shown in Caesar's iambic pentameter address to Antony below, where stressed syllables are, underlined:

Let not the piece of virtue which is set

Betwixt us, as the cement of our love (III. ii. 28)

The word occurs again with a stress on the first syllable in Pompey's speech:

For they have entertained cause enough

To draw their swords: but how the fear of us

May cement their divisions and bind up

The petty difference, we yet not know (II.i.49)

Other words such as aspect used to be pronounced with the stress on the second syllable, as seen in Cleopatra's talk about Pompey, "There would he anchor his aspect and die" (I.v.33).

Phonological changes were not the only changes that Modern English has undergone over the past four centuries. Other changes were taking place in the areas of vocabulary and grammar, and these will be explored below. 


\section{Noun Inflections}

A close reading of Antony and Cleopatra reveals interesting facts about noun inflections. Some noun inflections were still evolving while others were almost established and have survived without noticeable changes. Among these is the plural $-s$ inflection in present-day English, which remains almost the same as that used in Antony and Cleopatra, with $-s$ being added to the noun to form the plural. By the time Shakespeare wrote the play, the plural inflection had changed from the Old English plural system, where the plural of boc (book), for instance, was bec, and that of broc (breech) was brec. In Shakespeare's time, the plural $-s$ ending was commonly used. There were, however, some exceptions which have survived as "irregularities" in today's plural. These include nouns with unchanged plurals such as sheep and swine, and nouns whose plural is formed with vowel mutation rather than an ending, such as foot feet, tooth teeth, goose geese, man men, mouse mice, woman women, louse lice. However, there is evidence in Antony and Cleopatra of certain survivals of the old weak plural $-n$, such as eyne, which occurs in the song:

Come, thou monarch of the vine, Plumpy Bacchus with pink eyne! (II.vii.107)

Other words such as foe, knee, flea, hose, and shoe, had their plurals fon, kneen, fleen, hosen, and shoon respectively. The only survivals can be seen in the plural of $o x$ as oxen, the poetical word kine and mixed plurals like children and brethren (Baugh and Cable, 1993). The plural of these words has not survived but has instead conformed to the regular -s pattern, thus becoming eyes, foes, knees, and fleas, respectively. In other cases, old plural forms were used interchangeably with the new -s endings.

Some difference can also be seen in the dual treatment of particular nouns. Whereas the word news, for example, is always treated as singular today, it was treated in Elizabethan English as both singular and plural. This is evident in the opening scene of Antony and Cleopatra. When an attendant brings news from Rome, Antony expresses his irritation with the remark "Grates me, the sum" (I.i.18), where the -s ending with the verb grate shows that the word was treated as singular. But when Cleopatra objects by saying, "Nay, hear them Antony" (I.i.19), she gives evidence that the word could also be treated as plural.

Another noun inflection which has remained unchanged since Antony and Cleopatra is the genitive $s$, though, as Blake (1996) remarks, the double genitive was very common in Elizabethan English. The use of the double genitive in Antony and Cleopatra can be exemplified by Canidius' statement about Caesar: "This Speed of Caesar's carries beyond belief" 
(III.vii.74). Like the plural inflection, the genitive had already taken place by the time the play was written. However, the genitive $s$ seems to have been confused with what was thought to be a contraction of a noun and the pronoun his. The confusion can be traced back to the period of Middle English, when the unaccented -es of the genitive was frequently written and pronounced $-i s,-y s$. The genitive morpheme thus came to sound like the pronoun his when it was pronounced without the initial $h$ in unstressed environments. In this way, the pronunciation of stonis was the same as the pronunciation of ston is (his). Baugh and Cable (1993) note that as early as the thirteenth century the ending was sometimes written separately as though the possessive case were a contraction of a noun and the pronoun his. This notion prevailed for a long time, and can be seen to have survived in Shakespeare's Twelfth Night, ${ }^{4}$ when Antonio says:

I do not without danger walk these streets.

Once, in a sea-fight, 'gainst the count his galleys

I did some service. (Twelfth Night, III.iii.30)

Baugh and Cable (1993) point out that the notion continued to trouble people in the eighteenth century, as Dr. Johnson finds it hard to believe that the possessive ending is a contraction of his in such expressions as $a$ woman's beauty or a virgin's delicacy. He, himself, seems to have been conscious that its true source was the Old English genitive, but the error has left its trace in the apostrophe, which is still retained as a graphic convenience to mark the possessive. The difference between Elizabethan English and present-day English in noun inflections is hardly noticeable. More salient, perhaps, is the difference in personal pronoun use.

\section{Pronouns}

One of the main differences between present-day English and Elizabethan English is the use of personal pronouns. Three developments mark the use of the personal pronoun in the sixteenth century: the gradual transformation of the neuter genitive his into it and then its; the replacement of the forms thou, thy, and thee with the forms you, your, and you respectively, and the substitution of the nominative pronoun ye with you.

The gradual transformation of the neuter genitive his into it and its is one of the most interesting developments in the pronoun system. According to Blake (1996), the form of the possessive determiner it was rare, and its is an extension of the genitive ending $-s$ to it. It (rather than its) is the possessive determiner used by Antony in his comic description of the crocodile: "It is shaped, sir, like itself; and it is as broad as it hath breadth. 
It is just so high as it is, and moves with it own organs: it lives by that which nourisheth it; and the elements once out of it, it transmigrates" (II.vii.40). ${ }^{5}$

While the possessive determiner its was recorded at the end of the sixteenth century, its use did not become general until a century later, and it was spelled with an apostrophe until the end of the eighteenth century (Crystal, 1990, p. 201). The analogical form it's (now its) for the possessive of $i t$ was perhaps suggested by the possessive of nouns. Baugh and Cable (1993) point out that the first recorded instance of this form is in the Second Book of Madrigals, published by Nicholas Yonge in 1597. Because it does not occur in the Bible or any of Shakespeare's plays printed during his lifetime, the authors rule out the common use of it's even at the end of the sixteenth century. Only towards the end of the seventeenth century does the form its begin to have a rapid momentum:

Milton, although living until 1674, seems to have admitted it but grudgingly to his writings; there are only three occurrences of the word in all his poetry and not many in his prose. Yet so useful a word could hardly fail to win a place for itself among the rank and file of speakers. Towards the close of the seventeenth century its acceptance seems to have gained momentum rapidly, so that to Dryden (1631-1700) the older use of his as a neuter seemed an archaism worthy of comment. (p. 239)

In Antony's description of the crocodile above, it was used as a possessive determiner, thus giving evidence that the determiner was used with animate nonhuman entities. There is, however, other evidence in the play that such entities could be referred to with the possessive determiner his, and with the object pronoun him, as in the clown's answer to Cleopatra's request in which he refers to "the pretty worm of Nilus" with the pronouns his and him:

CLEOPATRA Hast thou the pretty worm of Nilus there, That kills and pains not?

CLOWN Truly, I have him: but I would not be the party that should desire you to touch him, for his biting is immortal; those that do die of it do seldom or never recover. (V.ii.247)

The pronoun his was used with neuter objects as the proper genitive form, ${ }^{6}$ as evident in Shakespeare's sonnet: 
Sometimes too hot the eye of heaven shines, And often is his gold complexion dimmed.

The pronoun continued to be used until the middle of the seventeenth century, a fact attested by the biblical If the salt have lost his savor, wherewith shall it be salted?

The possessive form mine, as used in Elizabethan English, is also different from modern use. In Antony and Cleopatra, mine occurs both as a possessive pronoun and a possessive adjective preceding vowels while $m y$ occurs as a possessive adjective before consonants and vowels. Today, possessive mine is used only as a pronoun. The use of mine and $m y$ is illustrated in Antony's speech in which he justifies why he did not provide Caesar with "arms and aid":

Neglected, rather;

And then when poison'd hours had bound me up

From mine own knowledge. As nearly as I may,

I'll play the penitent to you: but mine honesty

Shall not make poor my greatness, nor my power

Work without it. Truth is, that Fulvia,

To have me out of Egypt, made wars here;

For which myself, the ignorant motive, do

So far ask pardon as befits mine honour

To stoop in such a case. (II.ii.102)

In the speech above mine is used as a possessive determiner before the words own, honesty, and honour, while my is used before the words greatness and power. Other instances illustrate the use of mine as a possessive determiner before vowels: Cleopatra, eager to learn about the speech of Antony, uses mine before ear in her dialog with the messenger, "Mine ear must pluck it thence" (I.v.42). Caesar's blame of Antony includes the phrase mine intent :

You may be pleased to catch at mine intent

By what did here befal me. (II.ii.46)

And in Antony's justification of his position, the phrase "mine own peace" occurs. But he also uses the phrase "the article of my oath" where $m y$ precedes a vowel. Other instances of the use of $m y$ before a vowel can be seen in Antony's words:

The business she hath broached in the state

Cannot endure my absence. (I.ii.160) 
It can also be seen in Cleopatra's words "O, my oblivion is a very Antony"(I.iii.90), "Therefore be deaf to my unpitied folly" (I.iii.99), and in her orders to Charmian to give her the sleep-inducing mandragora so that she "might sleep out this great gap of time

my Antony is away" (I.v.6). Before Eros commits suicide, he bids Antony farewell, addressing him as "my emperor" (IV.xiv.90).

Another aspect of difference between today's English and the English of Antony and Cleopatra with respect to personal pronouns is the use of the second person pronoun. In Antony and Cleopatra the forms thou, thee, thy and thine were used along with the modern forms you, your, and yours. However, the use of one form or another reflects the attitude of one speaker towards his/her addressee and the tenor of dramatic discourse. The thou-forms designate social proximity and are properly used in commands and friendly contexts, whereas the you-forms denote social distance, formality, and respect. In his introduction to King Lear, Lott (1974) points out that the thou-forms are used in addressing social inferiors, members of one's family in normal and cordial terms of relationship, and supernatural beings, as in most Christian prayers in modern English.?

In his introduction to Hamlet (1968), he points out that the thou-you finer distinction was wearing thin in Shakespeare's days, which justifies why some usages in Hamlet "can hardly be explained by reference to this pattern" (p. xlii).

The distinction was much more clear-cut in earlier English: thou was used for the singular and you for the plural second person. In the thirteenth century the singular forms (thou, thy, thee) were used among familiars and in addressing children or persons of inferior rank, while the plural forms (ye, your, you) began to be used as a mark of respect in addressing a superior. The usage continued to reflect social distance or proximity until ye, your, and you became the usual pronoun of direct address regardless rank and intimacy. The thou-form ceased to be in general use at the end of the seventeenth century, though it continued in some regional dialects and religious styles (Crystal, 1990, p. 201).

In Antony and Cleopatra, warm exchanges between Antony and Cleopatra are characterized by the use of thou-forms:

CLEOPATRA I'll set a bourn how far to be beloved.

MARK Then must thou needs find out new heaven, new ANTONY earth. (I.i.17)

At no moment in the play is Cleopatra psychologically closer to Antony than when he dies. This proximity is revealed in part through the use of thou-forms: 
Noblest of men, woo't die?

Hast thou no care of me? Shall I abide

In this dull world, which in thy absence is

No better than a sty? (IV.xv.62)

Cleopatra's use of thou- or you-forms determines the psychological distance she is willing to maintain with Antony at particular points in the development of the drama. When messengers arrive from Rome with news for Antony, Cleopatra uses verbal strategies to ensure that Antony will brush aside the news and focus all his attention on her. Among the linguistic devices that mark her discourse with Antony is the use of the distant you-forms:

You must not stay here longer, your dismission

Is come from Caesar; therefore hear it, Antony. (I.i.27)

But because this distance has to be within control, she discontinues the use of you-forms, and reverts, instead, to the warmer thou-forms, addressing him with his name:

Call in the messengers. As I am Egypt's queen, Thou blushest, Antony; and that blood of thine Is Caesar's homager: else so thy cheek pays shame

When shrill-tongued Fulvia scolds. The messengers! (I.i.32)

When she gets upset because Antony has to go, she provokes him, using you-forms:

What says the married woman? You may go:

Would she had never given you leave to come!

Let her not say 'tis I that keep you here.

I have no power upon you; hers you are. (I.iii.23)

Another distinction marking the use of the second pronoun in Antony and Cleopatra is that between the objective you and the nominative ye. Such dichotomy does not exist in today's English. The form ye ceased to be used in the seventeenth century, and like the pronoun thou, indiscriminate use of the other form preceded its disappearance. Baugh and Cable (1993) point out that the two pronouns you and ye were at first nicely differentiated, but because both were unstressed in most times, they were often pronounced like ye. There was, however, a tendency to confuse the two forms at a fairly early stage. In the fourteenth century the accusative form you began to be used as a nominative, and in the fifteenth century 
the nominative ye began to be used for the objective case. Since that time, the two forms have apparently been used pretty indiscriminately until ye finally disappeared. In the early part of the sixteenth century some writers such as Lord Berners maintained the dichotomy (Baugh and Cable, 1993). The distinction was also observed in the Authorized version of the Bible (1611): no doubt but ye are the people, and wisdom shall die with you (Job).

In Antony and Cleopatra, ye occurs four times, and at no time does it occur in a nominative position. Mecaenus, urging the reconciliation of Antony and Caesar, says,

If it might please you, to enforce no further

The griefs between ye: to forget them quite

Were to remember that the present need

Speaks to atone you. (II.ii.106)

When Enobarbus tells Meanus that Octavia is now the wife of Marcus Antonius, Meanus expresses his surprise with what would currently translate as "I beg your pardon": "Pray ye, sir? (II.vi.110). It is also used by Dollabela in a conversation with Cleopatra: "If it might please ye," (V.ii.78). The inconsistent use of you and ye is clearly illustrated in Enobarbus' addresss to Pompey:

Sir,

I never loved you much; but I ha' praised ye,

When you have well deserved ten times as much

As I have said you did. (II.vi.77)

Other differences between Elizabethan and current English manifest themselves in the way adjectives were used.

\section{Adjectives}

The most important development affecting the adjective since Shakespeare's time seems to be in the area of comparison. By Shakespeare's day, the adjective had already lost all other endings that reflected gender, number and case. However, Shakespeare's use of the comparative and superlative forms of the adjective is quite different from current use.

In modern times, the comparative and superlative are consistently expressed by the endings -er and -est, or by the adverbs more and most. Unlike Shakespeare's use of comparatives and superlatives, the choice in today's English of -er or -est or the adverbs more and most follows a regular pattern. The endings -er and -est are added to monosyllabic 
adjectives to form the comparative and superlative, respectively. Thus the comparative and superlative forms of the adjective big are respectively bigger and biggest. The same endings are attached to disyllabic adjectives ending in -y, -ow, -le, -er, and -ure. Thus the comparative and superlative forns of the adjectives lovely, narrow, noble, clever, and mature are respectively lovelier - loveliest, narrower - narrowest, nobler - noblest, cleverer - cleverest, and maturer - maturest. Some common disyllabic adjectives can have the comparative and superlative forms either by adding -er and -est, or by adding the adverbs more and most before them. The comparative form of the two-syllable adjective common, for example, can be either commoner or more common, and the superlative form can be either commonest or the most common. Other disyllabic adjectives, ending with suffixes like -al as frugal, -ed as learned, -ful as careful, -ic as poetic, -ive as active, and -ous as famous take more and most. Adjectives other than those listed above form comparison only with more and most. The comparative form of expensive is more expensive, and the superlative is the most expensive.

Double comparatives occur in Antony and Cleopatra. ${ }^{8}$ When Caesar tells Octavia about Antony's return to Egypt, he mentions the names of the kings Antony has assembled in addition to "a more larger list of scepters" (III.vi.76). Another example of a double comparative is used by Cleopatra in her angry talk with the messenger:

Is he married?

I cannot hate thee worser than I do, If thou again say 'Yes'. (II.v.91)

The same form worser is used by Charmian in her talk with the soothsayer: "Our worser thoughts heavens mend!" (I.ii.56)

Periphrastic comparisons occur in Antony and Cleopatra with monosyllabic adjectives such as dear, mad, sweet, great, fit, narrow, weak, and noble. The phrase "more dear" is used by Caesar in his comforting address to his abused sister:

Welcome to Rome;

Nothing more dear to me (III.vi. 87).

Cleopatra uses the periphrastic comparison "more mad" in her response to Antony's fury:

Help me, my women! O, he is more mad

Than Telamon for his shield; the boar of Thessaly

Was never so emboss'd. (IV.xiii.3). 
The analytical form more tight (in the sense of more skillful) rather than tighter is used by Antony to refer to Cleopatra:

Thou fumblest, Eros, and my queen's a squire

More tight at this than thou. (IV.iv.15).

The -er inflection is also used with monosyllabic adjectives," as in the soothsayer's conversation with Charmian: "You shall be yet far fairer than you are."(I.ii.14), and in Enobarbus' talk about Cleopatra: "I have seen her die twenty times upon far poorer moment" (I.ii.132).

Periphrastic comparisons with most also occur with monosyllabic adjectives. ${ }^{10}$ The adverb most is used in the sense of very. Cleopatra is addressed by Antony as "Most sweet queen" (I.iii.32) in response to her remark that he does not keep an oath. When Lepidus attempts to reconcile the triumvirs, he says "That which combined us was most great, (II.ii.18). When Cleopatra decides to re-employ a messenger whom she had illtreated before; she reassures him she would reemploy him as he is "Most fit for business" (III.iii.36). Antony complains to Octavia that Caesar

Spoke scantly of me: when perforce he could not

But pay me terms of honour, cold and sickly

He vented them; most narrow measure lent me. (III.iv.6)

Octavia's jubilant reply to Antony's suggestion to act as mediator between him and Caesar includes the use of most with the monosyllabic weak:

The Jove of power make me most weak, most weak, Your reconciler! (III.iv.30)

Cleopatra is addressed by Iras as "most dear queen" (III.xi.26); Antony is addressed by Eros as "most noble sir" (III.xi.46), by Octavius Caesar as "most noble Antony" (III.ii.27), and by Mardian again as "most noble Antony" (IV.xiv.30). When he commits suicide, his blood is referred to by Dercetas as "most noble blood". (V:i.26).

The use of most with monosyllabic adjectives, however, is inconsistent. On one occasion Cleopatra is addressed by Iras as "most dear queen" (III.xi.26), and on another by Antony. as "my dearest Queen" (I.iii.18). Superlatives with -est inflections occur with the adjectives great, rough, and rude. Cleopatra, addressing Antony, tells 'im he's the greatest soldier of the world and yet the greatest liar: 
Or thou, the greatest soldier of the world,

Art turn'd the greatest liar. (I.iii.39)

In an exchange with Caesar, she refers to herself as "the greatest":

Be it known, that we, the greatest, are misthought

For things that others do. (V.ii.177)

The superlative -est form is used by Caesar in praise of Antpry

Thou didst drink

The stale of horses, and the gilded puddle

Which beasts would cough at. Thy palate then did deign

The roughest berry on the rudest hedge. (I.v.64)

Sometimes most is used as the equivalent of utmost. Thus, when Caesar tells Antony "With most gladness" (II.ii.172), his statement would be understood in modern times as with the utmost gladness.

Among the interesting usages of the adjectives in Antony and Cleopatra is the use of a transposed possessive determiner between the adjective and the noun. Thus it is common to see expressions like "Good my lord," for my good lord. This construction is used by Cleopatra in her address to Antony (III.xiii.109) and by Octavia in her address to Caesar (III.vi.55), and by Charmian in her address to Cleopatra: "Good your Highness, patience" (II.v.107). It is also used by Antony after he stabs himself: "Nay, good my fellows" (IV.xiv. 134).

Some quantifiers like all, each, both, every, other, and none are sometimes interchanged and used as pronouns. In the soothsayer's conversation with Charmian, every is used as pronoun:

If every of your wishes had a womb,

And fertile every wish, a million. (I.ii.36)

The use of none is different from current use. Cleopatra's talk with Antony exemplifies this use:

Eternity was in our lips and eyes,

Bliss in our brows' bent; none our parts so poor (I.iii.36)

Cleopatra also uses none as a substitute of a verb, when she decides she does not want to play billiards: "I'll none now" (II.v.9).

In Antony and Cleopatra, adjectives are used as adverbs, as shown by Lepidus' comment, "'Tis noble spoken" (II.ii.103). Demetrius, expressing 
regret over Antony's indifference to the news from Rome, uses the adjective full as adverb:

I am full sorry

That he approves the common liar. (I.i.59)

In current use, Demetrius' regret would have been "I am fully sorry." Like nouns, pronouns, and adjectives, verbs have undergone significant change since Antony and Cleopatra.

\section{Verbs}

One of the important differences between Elizabethan and today's English verb usage is the use of the auxiliary do in forming interrogative and negative constructions involving main verbs. In present-day English, the auxiliary $d o$, or its other forms does and $d i d$, is an indispensable element in forming such constructions. This did not seem to be the case in Elizabethan English, where interrogatives could commonly be formed by placing the main verb before the subject, and negatives could be formed by simply adding not after, and sometimes before, the verb.

Antony and Cleopatra abounds in examples of interrogatives lacking the auxiliary do. When Cleopatra asks Enobarbus about Antony, she says, "Saw you my lord?" (I.ii.73) and when she asks Charmian about him, she uses the same structure, except with one verb - walk:

O Charmian,

Where think'st thou he is now? Stands he, or sits he?

Or does he walk? or is he on his horse?

O happy horse, to bear the weight of Antony!

Do bravely, horse! for wot'st thou whom thou movest? (I.v.23)

Using tactics to prevent Antony from leaving, she asks, "What, says the married woman you may go" (I.iii.20). Her playful question to Mardian has no auxiliary: "Hast thou affections?" (I.v.12). In the same scene, she asks Alexas, "How goes it with my brave Mark Antony?" (I.v.38), and "Met'st thou my posts?" (I.v.62). When she decides to take her own life, she does not want to experience physical pain; she asks the clown:

Hast thou the pretty worm of Nilus there, That kills and pains not? (V.ii.243)

And when the clown states that he has it, she asks again. "Rememberest thou any that have died on't?" (248). Antony's inquiry about the details of 
his wife Fulvin's denth contains no auxiliary: "Where died she?" (l.ii.109), and when he gives orders that Thidias be whipped for having kissed Cleopatra's hand, he wants to make sure llie whipping was painful: "Cried he? and begg'd 'a pardon'?" (III.xiii.132). On another occasion, when he asks about Pompey's place, he places the main verb before the subject: "Where lies he?" (II.ii.164). Similar interrogatives appear in the

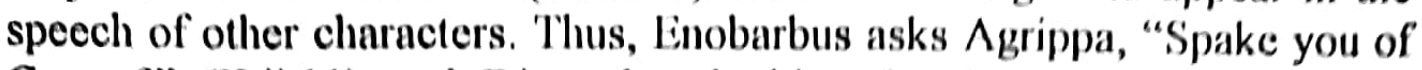
Caesar?" (II.ii.11) and Diomedes, looking for Antony, asks Dercetas, "Lives he?" (IV.xiv. 113). One of the soldiers asks, "Heard you of nothing strange about the streets?" (IV.iii.3). Enobarbus, inquiring about the state of affairs, asks, "How appears the fight?" (III.x.8). In the last scene, after the death of Antony, Enobarbus, Clcopatra, Iras, Eros, and Charmian, Dollabela asks "How goes it here?" (V.ii.324).

There are, however, other interrogatives with do, but these seem to be much less frequent than their non-auxiliary counterparts. Some of these occurrences will be illustrated below. Cleopatra wonders why Antony married Fulvia if ne did not love her: "Why did he marry Fulvia, and not love her?" (I.i.41). Eager to know what Octavia looks like, she showers the messenger with many questions involving the auxiliary do, "Didst thou behold Octavia?" (III.iii.7), "Didst hear her speak? is she shrilltongued or low?" (III.iii.12), and reverting to the more common pattern, she asks, "Bear'st thou her face in mind? is't long or round?" (III.iii.29). Antony, addressing Cleopatra, says, "Dost thou hear, lady?" (III.xiii.172) and shortly before he dies, he asks Diomedes about the time Cleopatra sent him, "When did she send thee?" (IV.xiv.118). When Alexas is asked by Cleopatra "How goes it with my brave Mark Antony?" (I.v.38) and "Met'st thou my posts?" (I.v.62), his answer involves a question formed with the auxiliary do:

"Ay, madam, twenty several messengers:

Why did you send so thick?" (I.v.63)

The now-regular interrogatives with do also appear in Agrippa's question to Caesar, "Who does he accuse?" (III.vi.23), in the collective speech of the soldiers, "How now? How now? Do you hear this?" (IV.iii.18), and in the third soldier's question, "Do you hear, masters? Do you hear?" (IV.iii.19).

Antony and Cleopatra also abounds in examples of negative sentences formed without the auxiliary $d o$. Sometimes not follows the main verb, but there are also instances in which not occurs before the verb, as in the exchange between Antony and Octavia in which Antony complains about Caesar's disrespect for him. Octavia's advice for Antony not to listen to rumors involves the use of not after the main verbs believe and stomach: 

ANTONY When the best hint was given him, he not took't, Or did it from his teeth.
OCTAVIA O my good lord,
Believe not all; or, if you must believe, Stomach not all. (III.iv.12)

Another dialog, this time between Charmian and Cleopatra, also illustrates the two different ways of forming the negative with main verbs:

CLEOPATRA Where is he?

CHARMIAN I did not see [emphasis added] him since.

CLEOPATRA See where he is, who's with him, what he does.

I did not send [emphasis added] you: if you find him sad,

Say I am dancing; if in mirth, report

That I am sudden sick: quick, and return.

[Exit ALEXAS

CHARMIAN Madam, methinks, if you did love him dearly,

You do not hold [emphasis added] the method to. enforce

The like from him.

CLEOPATRA What should I do, I do not [emphasis added]?

CHARMIAN In each thing give him way, cross him nothing.

CLEOPATRA Thou teachest like a fool: the way to lose him.

CHARMIAN Tempt him not [emphasis added] so too far; I wish, forbear:

In time we hate that which we often fear. (I.iii.12)

When Charmian asks the soothsayer to give her good fortune, his reply is in the non-auxiliary negative, "I make not, but foresee," (I.ii.13) and Alexas' advice to Charmian on the same occasion has no auxiliary either: "Vex not his prescience; be attentive" (I.ii.19). The switching from one negative construction to another may also be illustrated with two different utterances of one proposition. On one occasion, Pompey says, "I know not, Menas, How lesser enmities may give way to greater" (II.i.43), and on another, Caesar says, "I do not know, Mecaenas, ask Agrippa" (II.ii.17).

The use of the negative operator not after the verb seems to be typical of the imperative construction. In Antony and Cleopatra, all negative 
imperatives involving main verbs are formed with no auxiliary but with the use of the negative operator after the verb. The following are a few examples: "Speak not to us" (I.i.55), "Say not so, Agrippa" (II.ii.124), "Read not my blemishes in the world's report" (II.iii.5), "Take heed you fall not" (II.vii. 122), "Mock not, Enobarbus" (IV,vi.25), "Do not say so, my lord" (III.vi.62), "Make not your thoughts your prisons" (V.ii.185), "Speak softly, wake her not" (V.ii.316), and "Doubt not, sir" (I.iv.84).

The auxiliary do, however, occurs in compound tenses in Antony and Cleopatra, where modern English would use the simple tense. In Antony and Cleopatra, do and its derivatives are used in an auxiliary capacity without giving a separate meaning. In modern English this use would give special emphasis to the main verb. This verb construction can be seen in Antony's defense of himself before Caesar:

You do mistake [emphasis added] your business; my brother never

Did urge me in his act: I did inquire it. (II.ii.50)

It also occurs in Lepidus' speech:

When we debate

Our trivial difference loud, we do commit [emphasis added]

Murder in healing wounds. (II.ii.22)

Forestalling Antony's future, the soothsayer uses a compound tense:

If thou dost play [emphasis added] with him at any game, Thou art sure to lose. (II.iii.26)

\section{Verb inflections}

Another significant difference marking the use of the verb in Elizabethan English is the third person singular inflection. In Antony and Cleopatra, the two endings - eth and -s exist side by side. Today only -s has survived. Baugh and Cable (1993) maintain that all through the Middle English period, the -eth ending was the regular ending of the third person singular in the whole south and southeastern part of England. This district was the most influential in the formation of the standard speech. The -eth ending was universal in Chaucer: telleth, giveth, saith, doth, etc. In the fifteenth century, forms with $-s$ occasionally appeared, an event which Baugh and Cable find it difficult to account for as "it is not easy to see how the Northern dialects ... could have exerted so important an influence upon the language of London and the south" (p. 241). During the sixteenth century the $-s$ endings increase in number, especially in writings that 
seem to reflect the colloquial usage. By the end of the sixteenth century forms like tells, gives, says predominate, though in some words, such as doth and hath, the older usage may have been the more common. Speakers were free to use either form. During the first half of the seventeenth century, Baugh and Cable (1993) argue, the $-s$ ending had undoubtedly become universal in the spoken language, even though -eth continued to be quite commonly written. They quote Richard Hodges, a writer toward the middle of the seventeenth century, as saying "howsoever wee use to Write thus, leadeth it, maketh it, noteth it, raketh it per-fumeth it, \&c. Yet in our ordinary speech (which is best to bee understood) wee say leads it, makes it, notes it, rakes it, perfumes it." It is altogether probable that during Shakespeare's lifetime $-s$ became the usual ending for this part of the verb in the spoken language. (Baugh and Cable, 1993, p.241). Blake (1996) also remarks that the -eth ending continued to be used in writing until the seventeenth century, though it was confined to poetry where it could add an extra syllable when needed.

In Antony and Cleopatra, the -eth endings occur along with the modern -s endings. The -eth inflections are evident in Ventidius' words, "He purposeth [emphasis added] to Athens" (III.i.35), and in Charmian's speech, "E'en as the o'erflowing Nilus presageth [emphasis added] famine" (I.ii.45). The use of the -eth ending alongside with the modern -s ending is illustrated in Antony's comic description of the crocodile: "it lives [emphasis added] by that which nourisheth [emphasis added] it; and the elements once out of it, it transmigrates [emphasis added]." (II.vii.40). It can also be seen in Enobarbus' words: "it pleaseth [emphasis added] their deities to take the wife of a man from him, it shows [emphasis added] to man the tailors of the earth" (I.ii.152).

The verb forms associated with thou as subject end in -est, whether in the present or the past. The use of -est endings with the past tense is illustrated in the following speech by Caesar in praise of Antony:

When thou once

Wast beaten from Modena, where thou slew'st

Hirtius and Pansa, consuls, at thy heel

Did famine follow; whom thou fought'st against,

Though daintily brought up, with patience more

Than savages could suffer: thou didst drink

The stale of horses, and the gilded puddle

Which beasts would cough at.Thy palate then did deign

The roughest berry on the rudest hedge;

Yea, like the stag, when snow the pasture sheets,

The barks of trees thou browsed'st; on the Alps

It is reported thou didst eat strange flesh, 
Which some did die to look on. (I.iv.68)

The use of this ending in the present simple is shown in Cleopatra's tactical criticism of Antony: "Thou blushest, Antony" (I.i.30), and when he is dying she regretfully addresses him, "Hast thou no care of me?" (IV.xv.60). In a vow of loyalty, Antony swears:

As you shall give the advice. By the fire

That quickens Nilus' slime, I go from hence

Thy soldier, servant; making peace or war

As thou affect'st. (I.iii.71)

And in another expression of love, he says,

Our separation so abides, and flies,

That thou, residing here, go'st yet with me,

And I, hence fleeting, here remain with thee. (I.iii.105)

The -est ending is also used to express progressiveness. When Cleopatra rejects Charmian's advice, she tells her, "Thou teachest like a fool: the way to lose him" (I.iii.10).

Blake (1996) remarks that in 1400 the inflections for the present indicative were $-e$ (or zero), $-(e) s t$, $-(e) t h$ (or-s) for the first, second, and third person singular respectively, and -en/-eth for all persons in the plural. The first person soon lost its inflection, and the second person would lose its inflection as the plural ye/you was extended to the singular. The inflectional endings in the plural dropped out in the sixteenth century except in some conservative writings (pp.219-20).

The use of the progressive is quite rare in Antony and Cleopatra, and the present simple is used where the present progressive would be the proper alternative today. The increasing use of the progressive is one of the important developments that the verb system has undergone in later times (Baugh and Cable, 1993). One of the rare occurrences of the progressive is seen in Cleopatra's order to Charmian: "If you find him sad, say I am dancing" (I.iii.4). Elsewhere, the present simple is used in a progressive sense, as in "They cast their caps up and carouse together" (IV.xii.12), where the verbs cast and carouse are understood to occur in the progressive. On another occasion, Enobarbus uses the present simple weep, rather than are weeping:

What mean you, sir,

To give them this discomfort? Look, they weep;

And I, an ass, am onion-eyed: for shame, 
Another difference marking Elizabethan use of the verb is the occurrence of $b e$ with a past participle where has or has been would be deemed more appropriate in current times. In the very opening scene of Antony and Cleopatra, Philo comments on Antony's excessive behavior, saying that Antony "is become the bellows and the fan to cool a gipsy's lust" (I.i.10). In Caesar's camp, a messenger comments, "Antony is come into the field," where the present perfect has come would be used today. Similarly, Antony, asking about the schoolmaster, says "is 'a come back?" (III.xi.72).

Some verbs have past and past participle forms different from those used today. In Antony and Cleopatra, the past of speak is spake, and the past participle is spoke and spoken. Today the past of speak is spoke, and the past participle is spoken. Informing Antony of Cleopatra's last words, Mardian says, "The last she spake was 'Antony! most noble Antony!"” (IV.xiv.30). A guard describing Charmian's death says, "she stood and spake" (V.ii.337). Agrippa's apology to Antony includes spoke as a past participle: "Pardon what I have spoke," (II.ii. 141), and so does Caesar's reply to Antony's request to speak after Agrippa's speech:

Not till he hears how Antony is touch'd

With what is spoke already. (II.ii.144)

There is also one occurrence of the past drave rather than drove in the messenger's reply to Antony:

Ay. But soon that war had end, and the time's state

Made friends of them, joining their force 'gainst Caesar,

Whose better issue in the war, from Italy,

Upon the first encounter, drave [emphasis added] them. (I.ii. 84)

Another difference marking the use of verbs is the occurrence of compound participles. The compound participle construction, which arose in the sixteenth century (Baugh and Cable, 1993), does not seem to occur frequently in Elizabethan English. In Antony and Cleopatra, it occurs only twice in the characters' speeches. One such occurrence is depicted in Enobarbus' description of Cleopatra:

I saw her once

Hop forty paces through the public street;

And having lost [emphasis added] her breath, she spoke, and panted, 
That she did make defect perfection,

And, breathless, power breathe forth. (II.ii.235)

The other occurrence is illustrated in Eros' prosaic comment on Caesar's behavior: "Caesar, having made use of him in the wars 'gainst Pompey, presently denied him rivality" (III.v.7).

Some of Shakespeare's derivations have survived and others have been dropped out of use in time and derived in different ways. In Antony and Cleopatra there are examples of derivations that have not survived, such as mislike, misdoubt, and misthought. The current alternatives to these words are dislike, distrust, and misjudge. Other words in the play have either fallen out of use or undergone a process of semantic change. Some of the words that have dropped out of use include wot (know), anticked, burgonet, cantle, renege, methinks, wherefore, yond. The semantic change that other words have undergone will be explored below.

\section{Semantic features}

Many words in Antony and Cleopatra no longer mean what they used to mean in the sixteenth century. The semantic change these words have undergone can be described in terms of narrowing, broadening, meaning shift, melioration, and pejoration.

Narrowing, also known as "specialization" (Trask, 1996), is a semantic process in which the meaning of a word becomes narrower in the course of time. An instance of narrowing is illustrated in the word meat which Cleopatra utters in her statement, "Sir, I will eat no meat, I'll not drink, sir;" (V.ii.49) where meat means food. Nowadays, meat means a particular kind of food, flesh food, and not food in general. The former meaning of meat as food can also be inferred from King James version of Genesis: And God said, Behold, I have given you every herb bearing seed, which is upon the face of the earth, and every tree, in which is the fruit of a tree yielding seed; to you it shall be for meat. Interestingly, the current meaning of meat was denoted in Antony and Cleopatra by the word flesh, as shown in Caesar's praise of Antony:

On the Alps

It is reported thou didst eat some strange flesh, Which some did die to look on. (I.iv.68)

Another instance of narrowing is illustrated by the verb drink in Cleopatra's fear of defeat and humiliation in Rome. Like its current Egyptian and Turkish counterparts, the verb drink denoted, in addition to its other senses, the act of inhaling: 
In their thick breaths,

Rank of gross diet, shall be enclouded,

And forced to drink their vapour. (V.ii.213)

A third example of narrowing is the word witch, whose meaning was a magician of either sex, or magic itself. Like girl, which once meant a young person of either sex, the word witch is now restricted to females. The word is used by Charmian in her address to the male soothsayer: "I forgive thee for a witch" (I.ii.37), and by Antony in reference to Cleopatra: "The witch shall die" (IV.xii.47). In Antony's wish it simply means magic, "Now, the witch take me if I meant it thus" (IV.ii.37), a meaning that is no longer in use.

The meaning of purchase has also been narrowed to its present-day sense. In Antony and Cleopatra, it meant acquire, but today it means acquiring by paying money in return. The use of purchase in the sense of acquire is illustrated in Lepidus' defense of Antony:

His faults in him seem as the spots of heaven, More fiery by night's blackness; hereditary,

Rather than purchased. (I.iv.14)

The word honest occurs in Antony and Cleopatra with a meaning quite broader than that currently associated with it. In the comic exchange between Cleopatra and the eunuch Mardian, the word occurs in the sense of chaste:

$\begin{array}{ll}\text { Cleopatra } & \text {....Hast thou affections? } \\ \text { Mardian } & \text { Yes, gracious madam. } \\ \text { Cleopatra } & \text { Indeed? } \\ \text { Mardian } & \text { Not in deed, madam; for I can do nothing } \\ & \text { But what indeed is honest to be done. (I.v.16) }\end{array}$

In other parts of the play, the word occurs in the sense of truthfulness and chastity, as shown in the clown's answer to Cleopatra's question about the asp:

CLEOPATRA Remember'st thou any that have died on't?"

CLOWN Very many, men and women too. I heard of one of them no longer than yesterday: a very honest woman, but something given to lie; as a woman should not do, but in the way of honesty: how she died of the biting of it, what pain she felt: truly, she makes a very good report o'the worm. (V.ii.253) 
Another example of narrowed meaning is the word friend, which, in addition to the meanings it has today, also meant lover. Caesar says,

The queen

Of audience nor desire shall fail, so she

From Egypt drive her all-disgraced friend. (III.xii.22).

The current meaning of friend, on the other hand, is denoted in Antony and Cleopatra with the word master, as in the third soldier's talk, "Do you hear, masters? Do you hear?" (IV.iii.19).

Question words in Antony and Cleopatra were used with broader meanings. For example, what also meant who and why, as in Antony's question to the messenger "What are you?" (I.ii.108), and in Cleopatra's unfinished utterance just before she dies, "What should I stay?" (V.ii.309). The relativizer which was used for both animate and lifeless entities, as can be inferred from Dollabela's speech:

Caesar, 'tis his schoolmaster:

An argument that he is pluck'd, when hither

He sends so poor a pinion off his wing,

Which had superfluous kings for messengers

Not many moons gone by. (III.xii.6)

Broadening is another process of semantic change that word meaning undergoes. Sometimes referred to as widening (Wardhaugh, 1977) and generalization (Trask, 1996), the term denotes a process in which a word achieves in time a more general meaning so that it comes to mean everything it used to mean in addition to other denotations. An example of broadening can be seen in the word opinion said by Pompey, which meant a view of oneself:

but let us rear

The higher our opinion, that our stirring

Can from the lap of Egypt's widow pluck

The ne'er-lust-wearied Antony. (II.i.38)

Another example of broadening is seen in the word virtue which used to be associated with men, not women. In Cleopatra's warm reception of Antony, it means manly power:

Cleopatra: Lord of lords!

$\mathrm{O}$ infinite virtue, comest thou smiling from 
Today the word virtue applies to both men and women.

Another process of semantic change is known as synecdoche, in which the whole is used to denote the part, and a part used to denote the whole. An example of synecdoche is seen in Antony's request of Eros to help him wear his armor by referring to it as iron: "Eros! mine armour, Eros!" (IV.iv.1)

Pejoration, or degradation, is a process in which the meaning of a word comes to mean something inferior to what it originally meant. An example of pejoration is seen in Antony's affectionate address to Eros as his good "knave":

My good knave Eros, now thy captain is

Even such a body: here I am Antony:

Yet cannot hold this visible shape, my knave. (IV.xiv.14)

My good knave in the above quotation simply means my good servant. The word knave once meant only boy (Trask, 1996), but was demoted in modern times as a term of abuse meaning an unprincipled or crafty person, or a man of humble birth. These bad connotations were not part of the meaning of Antony's utterance.

Another example of pejoration can be seen in the word wench, which simply meant girl as can be inferred from Charmian's talk with the soothsayer: "Then belike my children shall have no names: prithee, how many boys and wenches must I have?" (I.ii.34). Now, wench also means a wanton woman. This is probably the meaning Agrippa invests on Cleopatra in describing her as "Royal wench" (II.ii.229). The opposite process is melioration, or elevation. In Antony and Cleopatra, the word Jack meant rascal, as in Antony's command, "Take hence this Jack, and whip him" (III.xiii.93). Today Jack means a man, a fellow, one who does heavy jobs, but not a rascal.

Another process of meaning change is known as semantic shift. In this process a word completely loses its original meaning and acquires a new one (Crowley, 1997). In the above discussion of narrowing, the word honest illustrated how a word can lose some of its meanings in the course of time. The current meaning of honest, however, is denoted in Antony and Cleopatra with the word proper; that is, the Elizabethan word proper has undergone a process of semantic shift. When Charmian praises the messenger as "a proper man" (III.iii.37), she means an honest man. Antony and Cleopatra teems with similar examples of semantic shift. In Scarus' statement, for example, ignorance means stupidity, and very means sheer: 
The greater cantle of the world is lost

With very ignorance; we have kiss'd away

Kingdoms and provinces. (III.x.8)

Avoid is used in the sense of go away, as when Cleopatra commands the guard, "avoid and leave him" (V.ii.242). Clip is used in the sense of embrace, as in Caesar's comment in the final speech of the play, in which he refers to Cleopatra and Antony:

No grave upon the earth shall clip in it

A pair so famous. (V.ii.356)

Formal is used in the sense of ordinary, as can be inferred from Cleopatra's anxious talk with the messenger,

If not well,

Thou shouldst come like a Fury crowned with snakes,

Not like a formal man. (II.v.41)

Another word that means ordinary in the play is modern whose old meaning is very different from current modern:

Say, good Caesar,

That I some lady trifles have reserved,

Immoment toys, things of such dignity

As we greet modern friends withal (V.ii.167)

Appointment is used by Antony in the sense of appearance and equipment. Talking to Scarus, he says,

They have put forth the haven,

Where their appointment we may best discover,

And look on their endeavour. (IV.x.9)

Approve is used in the sense of prove true. Demetrius regrets that Antony, with his excessive behavior, proves the truth of the rumors circulated about him in Rome:

I am full sorry

That he approves the common liar, who

Thus speaks of him at Rome. (I.i.61) 
The meaning of vacancy as leisure time in Antony and Cleopatra is different from current use. This is evident in Caesar's talk about Antony:

If he fill'd

His vacancy with his voluptuousness,

Full surfeits, and the dryness of his bones,

Call on him for't. (I.iv.27)

The word car in Antony's phrase "Phoebus' car" has also undergone a process of semantic shift, so that it does not mean chariot anymore:

He has deserved it, were it carbuncled

Like holy Phoebus' car.(IV.viii.29)

Present meant sudden, as shown in Agrippa's speech:

Pardon what I have spoke;

For 'tis a studied, not a present thought,

By duty ruminated. (II.ii.143)

In the messenger's talk with Antony, the word stiff meant unpleasant, and the word extended meant seized:

Labienus--

This is stiff news--hath, with his Parthian force,

Extended Asia. (I.ii.92)

Pompey's words illustrate the semantic shift the words pregnant and square have undergone. Unlike their meanings today, pregnant meant obvious while square meant quarrel:

Were't not that we stand up against them all, 'Twere pregnant they should square between themselves. (II.i.45)

\section{Summary}

The language of Antony and Cleopatra constitutes a linguistic limbo between Middle English and present-time English. It reflects a blossoming age characterized by vigor, creativity, initiative, and an adventurous spirit to tread courageously into terra incognita. The great changes that characterized the Renaissance could be felt in the language of the play, which teems with many clues as to what the language was 
like in the late sixteenth and early seventeenth century. The clues give the modern observer an idea about how words were pronounced, inflected, and syntactically arranged. One might think of Elizabethan English as a young and vigorous language in its carly adulthood, beginning to grow in unprecedented ways. This is implied in the tenn Early Modern English which indicates that the language was still in a process of ripening and that it had a long way to go before it reached a state of relative stability and refinement.

Like any living entity going through a process of ripening, Elizabethan English was in a state of flux, characterized by dualities in most linguistic features. By comparing the English of Antony and Cleopatra and modern English, one can see that English was far from reaching its zenith at that time. Yet, it is not very difficult to see how the writings of Shakespeare exercised a major influence that affected the course the language was to take in the seventeenth century and after. Shakespeare was free to shape the language to his own purposes. Rather than forcing his thought into ready-made molds dictated by the grammar of his time, he created his own molds to serve the ideas he wanted to express. In so doing, he used adjectives as nouns and adverbs, nouns as verbs, and created expressions that were to survive for centuries later, such as "my salad days," "play fast and loose," "beggars all description." If, as Knowles (1997) remarks, he used the language in a particularly bright way, the credit for that must go to him and not to the language.

Variations could be seen in every aspect of the language. Sounds were still changing, and there is evidence that the Great Vowel Shift was not completely accomplished by the beginning of the seventeenth century, the time the play was written. The word fear was pronounced like fair and room like Rome; the falling together of $i r, u r$, and $e r$ was under way but not complete, and the diphthongs [ay] and [aw] may have still been pronounced [i] and [u].

It is often the case in Antony and Cleopatra that the same grammatical concept could be denoted with two forms. As shown above, the plural of eye could be eyes or eyne; and news could be treated as singular or as plural. Many verbs, such as speak, had two past participle forms, spoke and spoken. The pronouns you and thou were used interchangeably. The nominative ye and the objective you were also used indiscriminately. The continuous tenses were used very rarely and were still developing into the way they are currently used. The $-s$ ending sometimes followed third person plural. The same ending also appears with the third person singular of the present tense along with the regular ending -eth. Adjectives such as worse and worser exist side by side. Besides, rules of forming the comparative were confused, with forms such as "most dear" and "dearest" existing side by side. Older word orders were still used as 
in Cleopatra's talk with the clown, "Take thou no care," "good my fellows!," "good my lord!" The negative was sometimes formed with a simple not before the verb, but many times after the verb, especially in the imperative mode, and sometimes with the auxiliary do. Interrogative sentences including main verbs were formed by simply inverting the subject-verb position, or by inserting a form of the operator $d o$. The use of $d o$ as an auxiliary verb with main verbs was still being refined: sometimes it was used with the negative and interrogative, and sometimes in affirmative assertions without having any meaning of its own. Question words had several meanings: at times what could be used instead of who and why. Quantifiers such as every could be used as pronouns. The personal pronouns he and $i t$ were used to refer to animate entities such as the crocodile and the worm. The possessive his was still used for lifeless neuter objects, and the possessive determiners mine and my were used interchangeably, though mine was used more frequently before vowels.

Some words have fallen out of use; others have survived, either retaining their meanings or acquiring new ones in the course of four hundred years. Some words like wot, renege, and methink are no longer used while others have undergone some process of semantic change. The terms broadening, narrowing, melioration, pejoration, and semantic shifts are used to describe various processes of semantic change. The meaning of virtue, for example, has broadened so that it now applies to both men and women, and the meaning of witch has narrowed so that it now applies to female magicians only. The meaning of Jack has been elevated, as it meant rascal in Shakespeare's time, while the word knave, which meant male servant, has taken on a pejorative meaning in current times. The word proper, which meant honest in Antony and Cleopatra, has also undergone a process of semantic shift. 


\section{Notes}

1. The symbols used in this study are those used in most standard American textbooks: [p] as in pit, [b] in bit, [m] in meat, [t] in time, [d] in dad, [n] in nice, [k] in

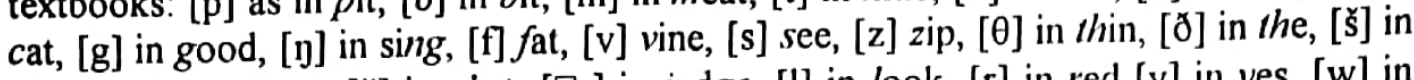
she [ž] in measure, [č] in chat, [ $\square$ ] in judge, [1] in look, [r] in red [y] in yes, [w] in we, $[\mathrm{h}]$ in happy, [i] in beat, $[\mathrm{I}]$ in bit, $[\mathrm{e}]$ in bait, $[\varepsilon]$ in bet, $[\mathrm{x}]$ in bat, $[\mathrm{u}]$ in soon, $[\Lambda]$ in $\mathrm{h} u \mathrm{t},[\mathrm{o}]$ in boat, [J] in small, [a] in father, [ə] in sofa, [ay] in five, [aw] in house, [כy] in boy.

2. By the end of the fifteenth century attempts were made to make an orthographic distinction between the two sounds [e:] and [i:]. The closer sound was often spelled with $e e$ or $i e$ as in seek and piece while the more open sound was as often spelled $e a$ as in sea and clean. But the practice was not consistently carried out (Baugh and Cable, 1993).

3. The sound [e:] was frequently shortened before alveolars and interdentals such as bread, breath, death, though the spelling remained the same.

4. The same notion can be seen in Troilus and Cressida, when Troilus says:

Ay, Greek; and that shall be divulged
In characters as well
Inflamed with Venus: never did young man fancy
With so eternal and so fix'd a soul. (Troilus and Cressida, V.ii)

5. The possessive it also occurs in other plays by Shakespeare. In Hamlet, for example, Horatio describing the ghost says, "it lifted up it head" (I.ii.216.) and in King Lear, the Fool says,

The hedge-sparrow fed the cuckoo so long,

That it had it head bit off by it young (I.iv.198).

6. In Middle English, the neuter pronoun was hit, his, hit, and it was pronounced without the initial $\mathrm{h}$ in unstressed position.

7. The use of thou is also retained in the grand style of poetry

8. Double comparatives occur in other plays by Shakespeare. In Julius Caesar, Mark Antony describes the wound given to Caesar by his close friend Brutus as the "most unkindest cut of all" (II.ii.187). Other occurrences are seen in other plays: "More elder" (The Merchant of Venice,V.iv.251), "More better" (The Tempest, 1.ii.19), "More nearer" (Hamlet, II.i.11), "More braver" (The Tempest, I.ii.439), "With the most boldest" (Julius Caesar, III.i.121), "To some more fitter place" (Measure for Measure (II.ii.16), "I would have been much more a fresher man" (Troilus and Cressida, V.vi.21)

9. Occurrences of the comparative infection -er with adjectives ending in -ing, -ed, id, -ain, -st, -ect can also be seen in other plays: "Horrider" (Cymbeline, IV.ii.331), "Curster" (The Taming of the Shrew, III.ii. 156), "perfecter" (Coriolanus, II.i.91), "certainer" (Much Ado about Nothing, V.iii.62). In current use, the analytical forms with more would be used.

10. In Shakespeare's plays, the superlative inflection -est occurs after -ent, -ing, -ed, ect. Examples include "violentest" (Coriolanus, IV.vi.73), "cursedst" (The Merchant of Venice, V.ii.46), "lyingest" (The Taming of the Shrew, I.ii.25), "perfectest" (Macbeth, I.v.2). 


\section{Bibliography}

Aitchison, J. (1992). Linguistics. NTC Publishing Group.

Baugh, A. C., \& Cable, T. (1993). A history of the English language. (4th ed.). London: Routledge.

Blake, N. F. (1996). A history of the English language. London: Macmillan Press Lid.

Crystal, David. (1990. The English language. Penguin Books.

Crowley, Terry. (1997). An introduction to historical linguistics. $3^{\text {rd }}$ ed.). Oxford: Oxford University Press.

Fromkin, V., \& Rodman, R. (1983). An introduction to language. ( $3^{\text {rd }}$ ed.). New York: Holt, Rinehart \& Winston.

Knowles, G. (1997). A cultural history of the English language. London: Arnold.

Lehmann, W. P. (1992). Historical Linguistics. ( $3^{\text {rd }}$ ed.). London: Routledge.

Lott, B. (Ed.). (1071). Antony and Cleopatra. Longman.

Lott, B. (Ed.). (1968). Hamlet. Longman.

Lott, B. (Ed.). (1974). King Lear. Longman.

Lott, Bernard. (1965). Macbeth. Longman.

Trask, R. L. (1996). Historical linguistics. London: Arnold.

Wardhaugh, R. (1977). Introduction to linguistics. ( $2^{\text {nd }}$ ed.). New York: McGraw-Hill Book Company.

Yule, G. (1985). The study of language. Cambridge: Cambridge University Press. 
Ayman El Gamal

Assistant professor of linguistics

English Department

Faculty of Al-Alsun

Minia University

The First Interantional Conference of the Faculty of Al-Alsun, Minia University,

" Egypt in World Literature "

14 - 15 April 2004

\section{Abstract \\ Lexical, Semantic and Syntactic Aspects of Shakespeare's Anthony and Cleopatra: A Diachronic study}

Anthony and Cleopatra, written by Shakespeare in about 1606, is fascinating in more ways than one. Not only does it capture the charming worlds of Egypt and Rome, the luxurious life in Cleopatra's palace, the strained politics in Rome, the conflict between love and duty, and the tension between the political world in Rome and the love affair of Anthony and Claopatra: but it also captures the way the English language was in the early seventeenth century, and how it has envolved into the English we speak and writre today. Yet, despite this difference, the version of English exhibited in Anthony and Cleopatra and the presentday English are traditionally classified as belonging to one linguistic period known as Modern English.

Although the langauge of Anthony and Cleopatra is poetic, mostly iambic pentameter, it can still lend itself to comparsion with present-day English in some respects. Further, it can provide clues as to the way some words were pronounced during Shakespeare $\mathrm{s}$ time. For example, yhe word cement, which is now two lines, which are written in a regular iambic pentameter:

Let not the piece of virtue which is set

Betwixt us, as the cement of our love (III.ii. 28)

(An underlind sylable is a stressed one)

This change of pronunciation of some words is not the only linguistic change that Anthony and Cleopatra reveals. The play reveals a version of English with lexical, syntactic, and semantic features that are quite different from present-day English. The differences between present-day English and Early modern English, however, are less dramatic than those between modern English and Middle English, or those between Middle English and old English. By examining the language of the play, the 
paper attempts to track down the changes that the English language has undergone ove the past four centuric: in terms of lexemes, structures and meaning. While the poetic language of the play is taken into account, a number of lexical, structural, and semantic changes are identified and analyzed.

The paper discusses the neologisms that Shkespeare coined in this play, and identifies the coinages which survived and those which did not. Structural aspects of early Modern English are also discussed as the occur in Anthony and Cleopatra. These include the way the negative was used, the use of double comparatives, noun and verb endings, the use of personal pronouns. Other aspects of Early modern English grammar that the paper analyzes include the use of the present simple instead of the present progressive in present-day English. Semantic changes are discussed under the rubrics narrowing, broadening, elevation, degradation, and semanticshifts. Examples of semantic shifts can be seen in the use of avoid in the sense of go away, clip in the sense of embrace and friend in the sense of lover. 


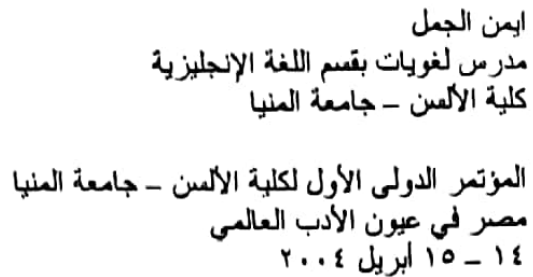

\section{ملخص}

الجوانب النحمية والدالاية والمفرداتية

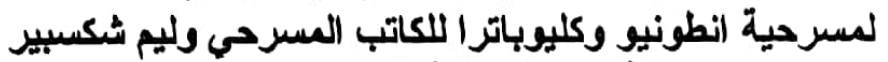

دراسة في علم اللغة التاريخي المقان

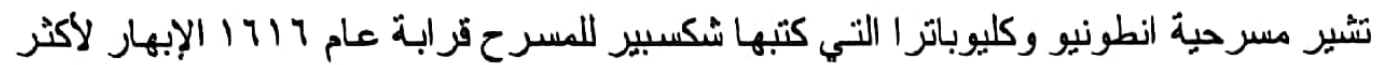

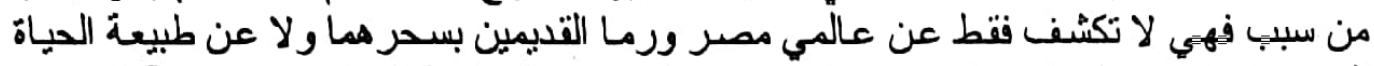

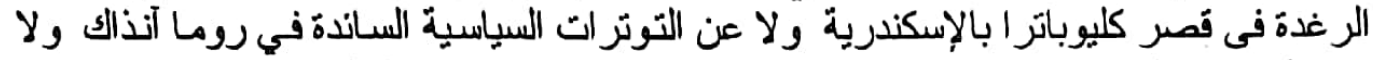

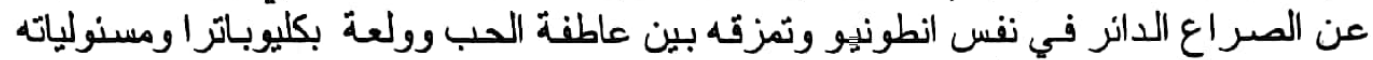

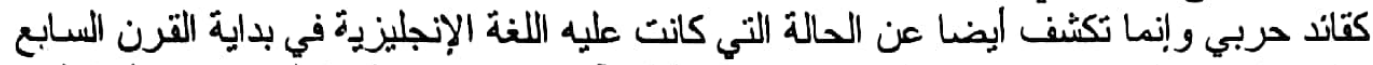

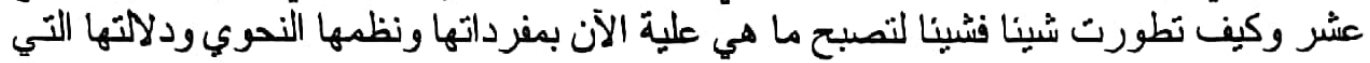

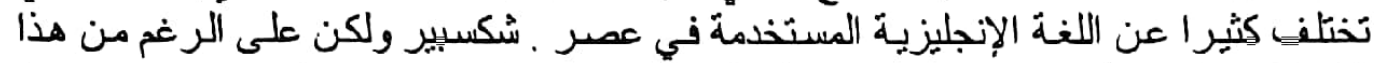
الاختلاف الكبير فان اللغويين يعتبرون اللغة الإنجليزية في القرن الإنية السابع عشر واللغنة الإنجليزية

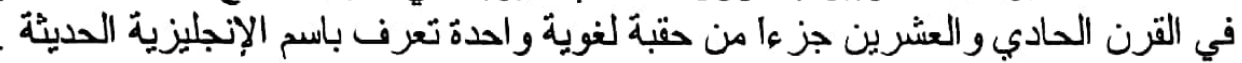

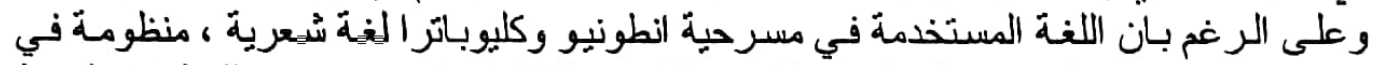

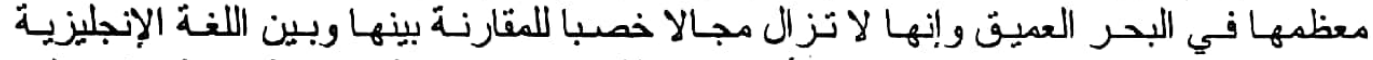

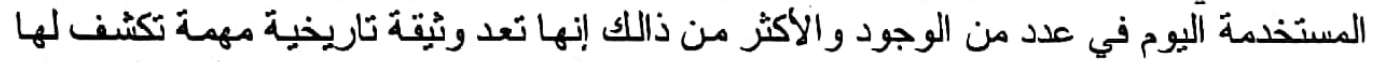

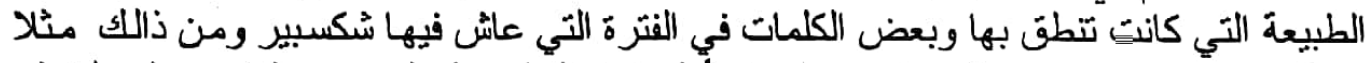

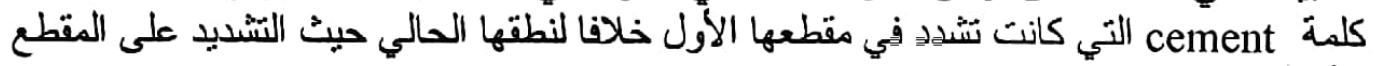
الأخير

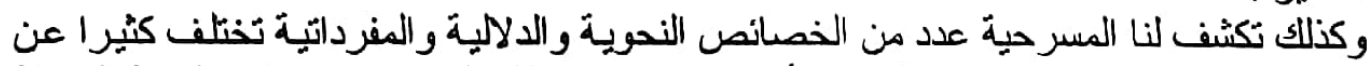

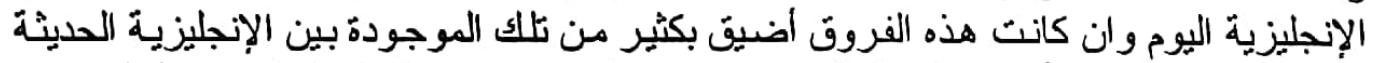

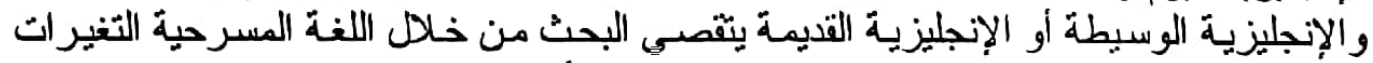

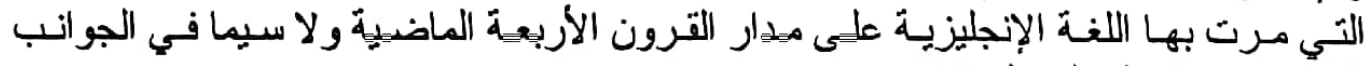

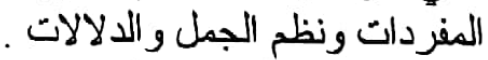

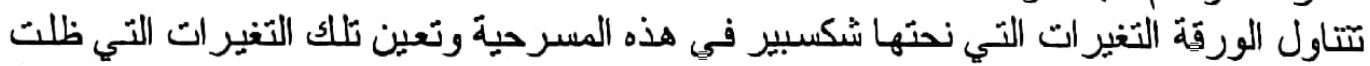

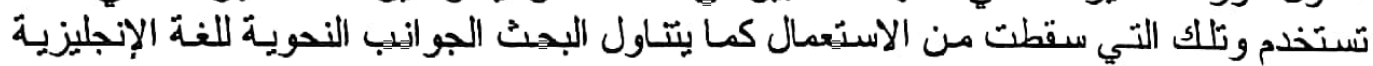

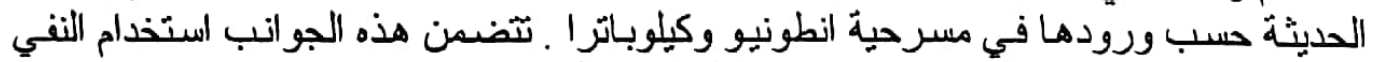

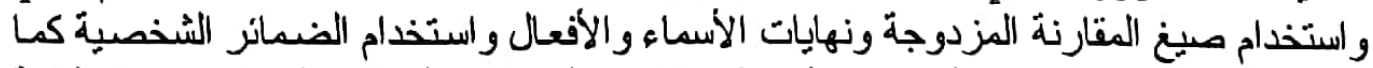

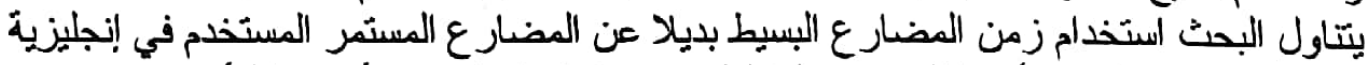

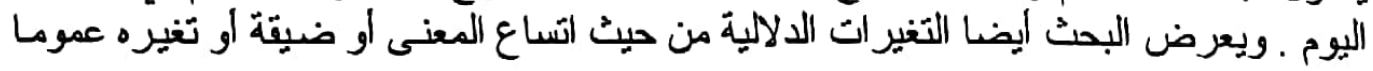

